\title{
ABCD1 wt Allele
}

National Cancer Institute

\section{Source}

National Cancer Institute. ABCD1 wt Allele. NCI Thesaurus. Code C142194.

Human ABCD1 wild-type allele is located in the vicinity of Xq28 and is approximately $20 \mathrm{~kb}$ in length. This allele, which encodes ATP-binding cassette sub-family D member protein, is involved in fatty acid import into the peroxisome. Mutation of the gene is associated with adrenoleukodystrophy and adult adrenomyeloneuropathy. 